\title{
Justismord og sakkyndighetsvesenet
}

1906 ble Henrik Andreassen Hetle (1870 - 1906) funnet død ved Hetlestølen i Gaular i Sunnfjord. Naboen Mikal Gjertsen Hetle (1853-1930) og hans sønn Ole (1887-1968) ble i 1907 kjent skyldige i overlagt drap. Dommen møtte massiv kritikk i mediene, da man mente de to dømte hadde vært utsatt for justismord. En rekke av samtidens intellektuelle, deriblant forfatterne Arne Garborg (1851-1924) og Inge Krokann (1893-1962), engasjerte seg i saken. Etter påtrykk fra opinionen ble saken tre ganger forsøkt gjenopptatt, men dette skjedde ikke før i 1943. Da ble begge de domfelte frifunnet og tilkjent erstatning, men Mikal Hetle døde i 1930 og fikk ikke oppleve dette. Debatten om dommen fra 1907 knyttet seg særlig til de rettsmedisinske vurderingene. Det var tema for Johan Scharffenbergs (1869-1965) to artikler i Tidsskriftet i 1909. der han kritiserte den manglende kvalitet på de sakkyndige undersøkelser som ble utført innledningsvis i saken. Han støttet dommens konklusjon, men mente at grunnlaget den bygde på var svært tynt og at prosessen burde undersøkes av en internasjonal kommisjon. Han benyttet også anledningen til å kritisere sakkyndighetsvesenet i sin alminnelighet (Tidsskr Nor Lægeforen 1909; 29: 552-3, 1065-9).

\section{Hetle-saken}

Jo mere jeg har søkt at tænke meg ind i saken, des sterkere er min «tro» blit, at de dømte er skyldige, og dog er jeg uenig i dommen. Ved en indiciedom maa alle andre logiske umuligheder være utelukket, det er ikke nok, at vedkommende sigtedes skyld er den sandsynligste av de foreliggende muligheter, den maa være den eneste logiske mulighet, naar der ikke foreligger noget direkte bevis. [...] Nu er der i vort land ikke saa ganske faa, som tror paa de dømtes uskyld, og jeg mener derfor, at den offentlige mening bør beroliges ved, at helt frit staaende utenlandske sakkyndige uttaler sig om sakens retsmedicinske side. Jeg kan ikke se noget verken for professor Harbitz personlig eller for den norske lægestand overhovedet saarende i en slik fremgangsmaade. Ialfald kan jeg forsikre, at der ikke fra min side tilsigtes nogen fornærmelse ved dette forslag, som kun har til maal at bringe ro i sindene. Disse sterke angræp paa vort retsvæsen er ikke heldige.

I denne forbindelse vil jeg også ytre ønske om en anden organisation av vort hele sakkyndighetsvæsen. Man kan ikke anse en hvilken som helst læge kompetent til at utføre f.eks. en legal obduktion, om hvis vanskelighed man paa forhaand ikke kan vite noget. Kun virkelige specialister bør opnævnes som sakkyndige for retten; kun specialutdannede sindsykelæger bør uttale seg om retspsykiatriske spørsmål, kun specialutdannede kemikere om retskemiske spørsmål, kun patologiske anatomer bør foretage legale obduktioner, kun fødselshjelpere uttale seg om svangerskap og fødsel o.s.v. Der bør skabes en ordning med kredsindeling af landet og faste sakkyndige paa de forskjellige områder og faste retsmedicinske stationer, saaledes at politi og paatalemyndighed altid vet, til hvilke sakkyndige de skal henvende seg $i$ hvert enkelt tilfælde. Utviklingen av vore kommunikationer vil muliggiøre henlæggelse av en stor del av landet under universitetslæreren i patologisk anatomi og retsmedicin. Retshaandhævelsen er samfundets høieste funktion, og derfor bør det aldrig hænde, at retten oppnævner som «sakkyndige» mænd med saa liten kyndighet, at deres erklæringer [...] nærmest er parodiske. 